Research Article

\title{
The Production of Green Diesel Rich Pentadecane (C15) from Catalytic Hydrodeoxygenation of Waste Cooking Oil using $\mathrm{Ni} / \mathrm{Al}_{2} \mathrm{O}_{3}-\mathrm{ZrO}_{2}$ and $\mathrm{Ni} / \mathrm{SiO}_{2}-\mathrm{ZrO}_{2}$
}

\author{
Momodou Salieu Sowe ${ }^{1,2,3}$, Arda Rista Lestari ${ }^{1}$, Eka Novitasari $^{1}$, M. Masruri ${ }^{1,2}$, \\ Siti Mariyah Ulfa ${ }^{1,2, *}$
}

${ }^{1}$ Chemistry Department, Faculty of Science, Brawijaya University, Malang, 65145, Indonesia.

${ }^{2}$ Synthesis and Catalysis of Natural Product Research Group, Faculty of Science, Brawijaya University, Jl. Veteran, Malang, 65145, Indonesia.

${ }^{3}$ Chemistry Unit, Division of Physical \& Natural Sciences, School of Arts \& Sciences, University of The Gambia, The Gambia.

Received: $6^{\text {th }}$ November 2021; Revised: $1^{\text {st }}$ December 2021; Accepted: $2^{\text {nd }}$ December 2021

Available online: 15 th December 2021; Published regularly: March 2022

\section{Abstract}

Hydrodeoxygenation (HDO) is applied in fuel processing technology to convert bio-oils to green diesel with metalbased catalysts. The major challenges to this process are feedstock, catalyst preparation, and the production of oxygen-free diesel fuel. In this study, we aimed to synthesize Ni catalysts supported on silica-zirconia and aluminazirconia binary oxides and evaluated their catalytic activity for waste cooking oil (WCO) hydrodeoxygenation to green diesel. $\mathrm{Ni} / \mathrm{Al}_{2} \mathrm{O}_{3}-\mathrm{ZrO}_{2}$ and $\mathrm{Ni} / \mathrm{SiO}_{2}-\mathrm{ZrO}_{2}$ were synthesized by wet-impregnation and hydrodeoxygenation of WCO was done using a modified batch reactor. The catalysts were characterized using X-ray diffraction (XRD), Xray fluorescence (XRF), and scanning electron microscopy - energy dispersive X-ray spectroscopy (SEM-EDS), and $\mathrm{N}_{2}$ isotherm adsorption-desorption analysis. Gas chromatography - mass spectrometry (GC-MS) analysis showed the formation of hydrocarbon framework $n$ - $\mathrm{C}_{15}$ generated from the use of $\mathrm{Ni} / \mathrm{Al}_{2} \mathrm{O}_{3}-\mathrm{ZrO}_{2}$ with the selectivity of $68.97 \%$ after a $2 \mathrm{~h}$ reaction. Prolonged reaction into $4 \mathrm{~h}$, decreased the selectivity to $58.69 \%$. Ni/ $\mathrm{SiO}_{2}-\mathrm{ZrO}_{2}$ catalyst at $2 \mathrm{~h}$ showed selectivity of $55.39 \%$ to $n$ - $\mathrm{C}_{15}$. Conversely, it was observed that the reaction for $4 \mathrm{~h}$ increased selectivity to $65.13 \%$. Overall, $\mathrm{Ni} / \mathrm{Al}_{2} \mathrm{O}_{3}-\mathrm{ZrO}_{2}$ and $\mathrm{Ni} / \mathrm{SiO}_{2}-\mathrm{ZrO}_{2}$ catalysts produced oxygen-free green diesel range $(n$ $\mathrm{C}_{14}-\mathrm{C}_{18}$ ) enriched with $n$ - $\mathrm{C}_{15}$ hydrocarbon. Reaction time influenced the selectivity to $n$ - $\mathrm{C}_{15}$ hydrocarbon. Both catalysts showed promising hydrodeoxygenation activity via the hydrodecarboxylation pathway.

Copyright (C) 2021 by Authors, Published by BCREC Group. This is an open access article under the CC BY-SA License (https://creativecommons.org/licenses/by-sa/4.0).

\section{Keywords:}

hydrodeoxygenation; waste cooking oil; green diesel; alumina; zirconia; silica; $\mathrm{Ni} / \mathrm{Al}_{2} \mathrm{O}_{3}-\mathrm{ZrO}_{2} ; \mathrm{Ni} / \mathrm{SiO}_{2}-\mathrm{ZrO}_{2}$

How to Cite: M.S. Sowe, A.R. Lestari, E. Novitasari, M. Masruri, S.M. Ulfa (2022). The Production of Green Diesel Rich Pentadecane (C15) from Catalytic Hydrodeoxygenation of Waste Cooking Oil using $\mathrm{Ni}_{2} / \mathrm{Al}_{2} \mathrm{O}_{3}-\mathrm{ZrO}_{2}$ and $\mathrm{Ni} / \mathrm{SiO}_{2}-\mathrm{ZrO}_{2}$. Bulletin of Chemical Reaction Engineering \& Catalysis, 17(1), 135-145 (doi:10.9767/bcrec.17.1.12700.135-145)

Permalink/DOI: https://doi.org/10.9767/bcrec.17.1.12700.135-145

\section{Introduction}

The massive production of $\mathrm{CO}_{2}$ from the combustion of fossil fuel is suspected to initiate the

* Corresponding Author.

Email: ulfa.ms@ub.ac.id (S.M. Ulfa);

Telp: +62-341-575835, Fax: +62-341-554403 rapid change in global climate conditions [1]. Consequently, to slow down, the environmental destruction caused by fossil fuel, decreasing dependence on the use of crude oil is one of the choices. Biofuels can be directly obtained from biomass to serve as an alternative, clean and sustainable energy resource to fossil fuel and 
cut down on carbon emissions in the atmosphere. The utilization of biomass [2] and fatty oil [3] renewable feedstock for biofuel production has been reported. Both feedstocks have a problem on a limitation for the mass production of bio-oil, but the low cost and abundant material become an interesting point that may decrease consumption of fossil oil.

Large scale production and the commercial use of the first generation fatty acid methyl ester (FAME) biodiesel is constrained due to high oxygen content which reduces energy density, high viscosity, and poor storage properties $[4,5]$. Therefore, many researchers are developing different routes for converting fatty oil into biodiesel which is fully compatible with fossil diesel fuel. The second-generation biodiesel is called 'green diesel' that is paraffin-rich diesel that is free from oxygen, sulfur, nitrogen, or aromatic hydrocarbon. The green diesel is produced from the catalytic hydrotreating of renewable feedstock containing triglycerides and fatty acids [6]. Green diesel has a high cetane value and flash value suitable as an alternative fuel for internal combustion engines (ICEs) [7]. Biodiesel production from waste material may ease waste management challenges of waste disposal. Waste cooking oil is an environmentally benign and non-edible feedstock rich in free fatty acid content. Waste cooking oil is a prospective feedstock in catalytic hydrodeoxygenation (HDO) for green diesel production [8].

A series of HDO reactions using WCO feedstock is reported in many aspects. A variety of product distribution mostly heavier straightchain hydrocarbon within the diesel range $\left(\mathrm{C}_{15}-\mathrm{C}_{18}\right)$ has previously been generated from waste cooking oil and fatty acids via catalytic hydrodeoxygenation [9]. In a report by [10], the effect of catalyst support on HDO of waste cooking oil was investigated in a stainless steel autoclave reactor. Product distribution is reported to vary between $n$ - $\mathrm{C}_{17}$ and $n$ - $\mathrm{C}_{18}$ hydrocarbon depending on support type. In other reports, $n-\mathrm{C}_{17}$ and $n$ - $\mathrm{C}_{18}$ were detected as major constituents in products obtained from HDO of waste cooking oil [11-13]. The product distribution of hydrocarbon between $\mathrm{C}_{15}-\mathrm{C}_{18}$ from biobased feedstock possesses diesel fuel properties similar to conventional diesel with high energy density and good oxidative stability [14].

Heterogeneous bimetallic sulfur-free catalysts, such as $\mathrm{NiCu}$ [15], NiMo [16], and NiW [17] on mesoporous and oxide supports, have been studied extensively in the hydrodeoxygenation of fatty acids of vegetable oil to biodiesel. Advantages of heterogeneous Ni-based catalysts are larger active surfaces for better cata- lytic activity, easy recovery from the reaction mixture, and reusability. Noble metal catalysts have shown outstanding activity in HDO of bio-oil for biodiesel production $[12,18]$. Despite the high catalytic activity, noble metals are expensive and inflate catalyst production costs. In our previous works, we reported an interesting phase phenomenon with $\mathrm{SiO}_{2}$ in $\mathrm{Ni} / \mathrm{ZrO}_{2}$ $\mathrm{SiO}_{2}$ nanocomposite synthesized by the wet impregnation method [19]. $\mathrm{SiO}_{2}$ underwent crystallinity transformation from crystalline to amorphous due to composite formation with $\mathrm{ZrO}_{2}$. A reverse-phase formation from amorphous to crystalline $\mathrm{SiO}_{2}$ was detected after $\mathrm{Ni}$ impregnation. To understand the effect of binary support on $\mathrm{Ni}$ catalyst, we tested $\mathrm{Ni} / \mathrm{SiO}_{2}$ $\mathrm{ZrO}_{2}$ for phenol hydrodeoxygenation in a stainless autoclave batch reactor [20]. The catalyst showed remarkable activity for ring hydrogenation with the selective formation of cyclohexanol and cyclohexanone. In another report, $\mathrm{Ni}$ supported by single oxides $\mathrm{SiO}_{2}, \mathrm{ZrO}_{2}$, and $\mathrm{Al}_{2} \mathrm{O}_{3}$ were synthesized and tested for phenol hydrodeoxygenation [21]. Ni/ $\mathrm{SiO}_{2}$ showed activity for phenol ring-opening with product formation of 2-methyl-1-butanol and $\mathrm{Ni} / \mathrm{ZrO}_{2}$ promoted hydrogenation leading to the formation of cyclohexanone.

In this work, we synthesized $\mathrm{Ni}$ catalysts supported on binary oxides of $\mathrm{SiO}_{2}-\mathrm{ZrO}_{2}$ and $\mathrm{Al}_{2} \mathrm{O}_{3}-\mathrm{ZrO}_{2}$ by the wet impregnation method. Catalyst physicochemical properties, such as: crystalline structure, Ni loading, surface morphology, BET surface area, pore volume, and pore diameter, were studied by XRD, XRF, SEM-EDS, and $\mathrm{N}_{2}$ isotherm adsorptiondesorption analysis respectively. Catalyst performance was tested for waste cooking oil hydrodeoxygenation to green diesel in a modified batch reactor at $350^{\circ} \mathrm{C}, 2 \mathrm{MPa} \mathrm{H}_{2}, 2 \mathrm{~h}$, and $4 \mathrm{~h}$. All reactions were conducted in a solvent-free environment. Analysis using GC-MS gave the formation of $n-\mathrm{C}_{15}$ as major constituents in green diesel fraction. To our knowledge, this is the first report on the production of green diesel rich with $n-\mathrm{C}_{15}$. It is suggested that the predominant reaction might be catalytic decarboxylation of the oleic acid.

\section{Materials and Methods}

\subsection{Materials}

Analytical grade $\mathrm{ZrOCl}_{2} .8 \mathrm{H}_{2} \mathrm{O}$ (Merck $\mathrm{KGaA}$ ) and $\mathrm{Ni}\left(\mathrm{NO}_{3}\right)_{2} \cdot 6 \mathrm{H}_{2} \mathrm{O}$ (Merck KGaA) were used as precursors for $\mathrm{ZrO}_{2}$ and Ni-based metal sources. $\gamma-\mathrm{Al}_{2} \mathrm{O}_{3}$ (Merck KGaA) and $\mathrm{SiO}_{2}$ (0.063-0.200 mm) Merck KGaA were used as support materials. Ammonium solution 
$\left(\mathrm{NH}_{4} \mathrm{OH}\right)$, silver nitrate solution $\left(\mathrm{AgNO}_{3}\right)$, deionized water (DI), and anhydrous sodium sulfate $\left(\mathrm{Na}_{2} \mathrm{SO}_{4}\right)$ were used as received.

\subsection{Methods}

\subsubsection{Catalyst preparation}

The binary oxide $\mathrm{Al}_{2} \mathrm{O}_{3}-\mathrm{ZrO}_{2}$ and $\mathrm{SiO}_{2}-\mathrm{ZrO}_{2}$ was previously prepared in a $1: 1(\mathrm{wt} / \mathrm{wt})$ ratio according to the reported methods [19,20]. $10 \mathrm{~g}$ of $\mathrm{Al}_{2} \mathrm{O}_{3}-\mathrm{ZrO}_{2}$ was prepared by dissolving $13 \mathrm{~g}$ of $\mathrm{ZrOCl}_{2} .8 \mathrm{H}_{2} \mathrm{O}$ in deionized water (DI) with the dropwise addition of $\mathrm{NH}_{4} \mathrm{OH}$ until $\mathrm{pH} 8$ was identified by the formation of $\mathrm{Zr}(\mathrm{OH})_{4}$ as a white precipitate. The precipitate was directly mixed with $5 \mathrm{~g}$ of $\gamma-\mathrm{Al}_{2} \mathrm{O}_{3}$ which was then aged for $10 \mathrm{~h}$ at a constant temperature of $75^{\circ} \mathrm{C}$. After aging, the solid mixture was dried to constant weight and calcined under $\mathrm{N}_{2}$ gas for $5 \mathrm{~h}$ at $500{ }^{\circ} \mathrm{C}$ to obtain the $\mathrm{Al}_{2} \mathrm{O}_{3}-\mathrm{ZrO}_{2}$ composite. The $\mathrm{SiO}_{2}-\mathrm{ZrO}_{2}$ composite was also prepared by a similar procedure by mixing $10 \mathrm{~g}$ of $\mathrm{SiO}_{2}$ with the $\mathrm{Zr}(\mathrm{OH})_{4}$ precipitate, aged, dried, and calcinated to give $\mathrm{SiO}_{2}-\mathrm{ZrO}_{2}$ composite.

The $\mathrm{Ni} / \mathrm{Al}_{2} \mathrm{O}_{3}-\mathrm{ZrO}_{2}$ and $\mathrm{Ni} / \mathrm{SiO}_{2}-\mathrm{ZrO}_{2}$ were prepared by the wet impregnation method, by mixing $7.4 \mathrm{~g}$ of $\mathrm{Ni}\left(\mathrm{NO}_{3}\right)_{2} \cdot 6 \mathrm{H}_{2} \mathrm{O}$ with $10 \mathrm{~g}$ of $\mathrm{Al}_{2} \mathrm{O}_{3}-\mathrm{ZrO}_{2}$ in DI water. The mixture was agitated overnight and then evaporated to dryness to form a solid mixture. The solid mixture was calcined at $500{ }^{\circ} \mathrm{C}$ for $5 \mathrm{~h}$ under continuous $\mathrm{N}_{2}$ gas flow followed by reduction under continuous $\mathrm{H}_{2}$ gas flow at $500{ }^{\circ} \mathrm{C}$ for $5 \mathrm{~h}$ to form $15 \%$ $\mathrm{Ni} / \mathrm{Al}_{2} \mathrm{O}_{3}-\mathrm{ZrO}_{2}(\mathrm{Ni} / \mathrm{AZ})$ and $15 \% \mathrm{Ni} / \mathrm{SiO}_{2}-\mathrm{ZrO}_{2}$ (Ni/SZ), respectively.

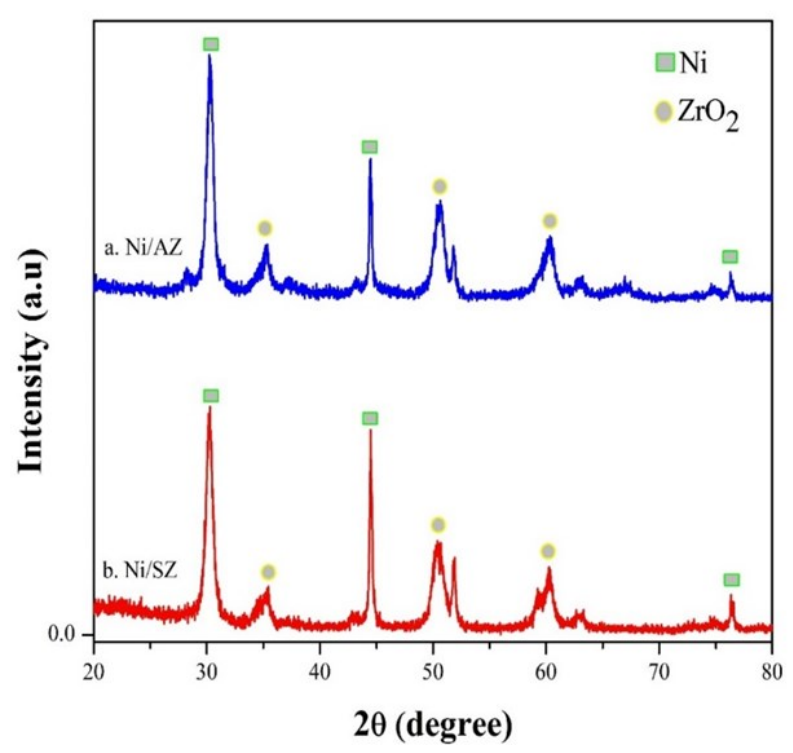

Figure 1. XRD spectra of (a) $\mathrm{Ni} / \mathrm{Al}_{2} \mathrm{O}_{3}-\mathrm{ZrO}_{2}$ and (b) $\mathrm{Ni} / \mathrm{SiO}_{2}-\mathrm{ZrO}_{2}$.

\subsubsection{Catalyst characterization}

The crystal structures of the catalysts were analyzed using an X-Ray Diffractometer (XRD) PAN Analytical E'xpert Pro operated at $40 \mathrm{kV}$, $35 \mathrm{~mA}$ with $\mathrm{Cu}-\mathrm{K}_{\alpha}$ radiation of $\lambda=1.54060$ and $2 \theta=10^{\circ}-80^{\circ}$. SEM measurements at a scan rate of $1 \%$ min were conducted to determine the catalyst surface morphology. The SEM data were collected from PHENOM. Specific surface area is determined from BET isotherms using nitrogen gas at $77 \mathrm{~K}$ measured by Belsorp Mini II (Microtrac BEL) at $77 \mathrm{~K}$. X-Ray Fluorescence (XRF) Pan Analytical Type Minipal 4 was used to determine actual $\mathrm{Ni}$ loading on $\mathrm{Ni} / \mathrm{Al}_{2} \mathrm{O}_{3}$ $\mathrm{ZrO}_{2}$ and $\mathrm{Ni} / \mathrm{SiO}_{2}-\mathrm{ZrO}_{2}$, respectively. Potassium Bromide (KBr) pellets with 400-4000 $\mathrm{cm}^{-1}$ spectral range in a Shimadzu 8400 S were used to record the Fourier-Transform Infrared Spectra (FT-IR) of the catalysts.

\subsubsection{Waste cooking oil pre-treatment method}

Waste cooking oil pre-treatment was conducted according to a report by Li et al. [22]. A $500 \mathrm{~g}$ of the waste cooking oil collected from a halal food court center in Brawijaya University was mixed with $700 \mathrm{~mL}$ of saturated salt solution and heated at $80{ }^{\circ} \mathrm{C}$ for $3 \mathrm{~h}$ under continuous magnetic stirring. After heating, the solution was placed in a separatory funnel for $12 \mathrm{~h}$ and the upper oil layer was collected and mixed with $500 \mathrm{~mL}$ of DI water containing $4 \mathrm{~g}$ of activated carbon (AC). The mixture was heated at $80{ }^{\circ} \mathrm{C}$ for $3 \mathrm{~h}$ with stirring. Afterward, the activated carbon was removed by vacuum filtration and the oil was placed in a separatory funnel for layering. The upper oil layer was collected and dried with anhydrous $\mathrm{Na}_{2} \mathrm{SO}_{4}$. The $\mathrm{Na}_{2} \mathrm{SO}_{4}$ was removed by filtration and the obtained oil was then stored in an oven at $105^{\circ} \mathrm{C}$ for $12 \mathrm{~h}$.

A $10 \mathrm{~g}$ of the pre-treated waste cooking oil was trans-esterified with methanol and $\mathrm{NaOH}$ catalyst as reported [23]. The free fatty acid (FFA) content of the oil was determined by Gas Chromatography-Mass Spectrometer injected on a Shimadzu (GCMS QP2010s) with an HP5MS column and FID detector.

\subsubsection{Waste cooking oil hydrodeoxygenation re-} action

The hydrodeoxygenation reaction (HDO) was according to published methods by our group [24]. Before the reaction, each catalyst $\mathrm{Ni} / \mathrm{Al}_{2} \mathrm{O}_{3}-\mathrm{ZrO} 2$ and $\mathrm{Ni} / \mathrm{SiO}_{2}-\mathrm{ZrO}_{2}(0.2 \mathrm{~g})$ was activated by heating at $350{ }^{\circ} \mathrm{C}$ for $1 \mathrm{~h}$ under 2 $\mathrm{MPa} \mathrm{H}_{2}$ gas in the reactor before each run. HDO reaction was started by inserting $25 \mathrm{~mL}$ 
of the pre-treated waste cooking oil in the reactor containing the activated catalyst. Each reaction was tested at $350{ }^{\circ} \mathrm{C}, 2 \mathrm{MPa}$ pure $\mathrm{H}_{2}$ gas pressure for $2 \mathrm{~h}$ and $4 \mathrm{~h}$ for each run. The HDO liquid organic products obtained were analyzed using GC-MS injected on a Shimadzu QP2010s. GC-MS analysis was conducted at an oven temperature of $40{ }^{\circ} \mathrm{C}$, gradually increased to 250 ${ }^{\circ} \mathrm{C}$, and held for 2 mins with a splitless injection mode. The gas pressure was $49.5 \mathrm{kPa}$ at a flow rate of $30 \mathrm{~mL} / \mathrm{min}$. A Shimadzu (8400S) Fourier-Transformed Infrared Spectrophotometer instrument was used to analyze the liquid organic products before GC-MS analysis.

\section{Results and Discussion}

\subsection{Catalyst Characterizations}

Figure 1 illustrates the XRD patterns of $\mathrm{Ni} / \mathrm{Al}_{2} \mathrm{O}_{3}-\mathrm{ZrO}_{2}$ and $\mathrm{Ni} / \mathrm{SiO}_{2}-\mathrm{ZrO}_{2}$ catalysts. From the patterns, the metallic nickel phase is detected at $2 \theta=44^{\circ}$ (111) and $76^{\circ}(220)$ according to JCPDS data 96-210-2279. The absence of $\mathrm{NiO}$ at $2 \theta=37^{\circ}, 43^{\circ}$, and $64^{\circ}$ was confirmed [25]. The additional heating at $500{ }^{\circ} \mathrm{C}$ for $5 \mathrm{~h}$ under $\mathrm{H}_{2}$ flow completely reduced ionic nickel into metallic nickel. Analysis of the support showed that zirconia is detected in two phases, monoclinic $\left(m-\mathrm{ZrO}_{2}\right)$ at $2 \theta=30^{\circ}$ and $50^{\circ}$, and tetragonal $\left(t-\mathrm{ZrO}_{2}\right)$ at $2 \theta=35^{\circ}, 51^{\circ}$, and $60^{\circ}$,

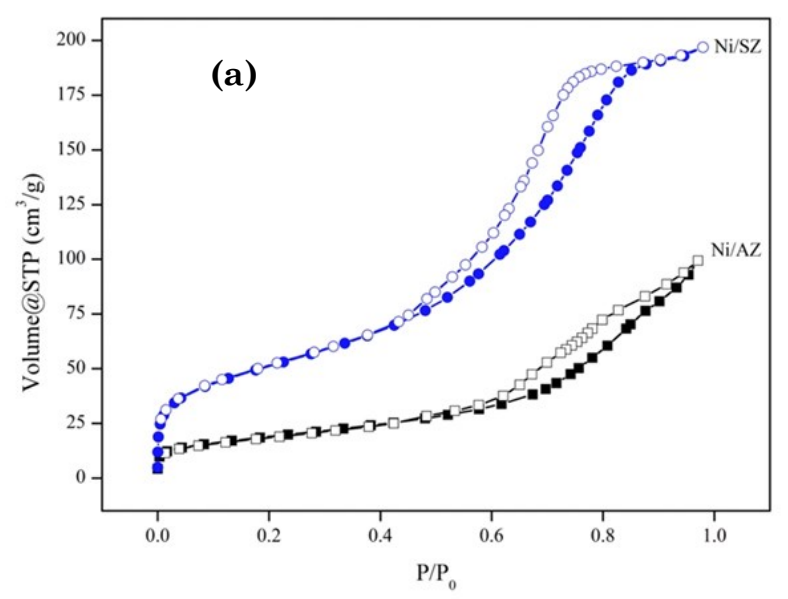

similar to Ulfa et al. [19]. Distinctive missing patterns are observed for $\mathrm{Al}_{2} \mathrm{O}_{3}$ and $\mathrm{SiO}_{2}$. This is attributed to the formation of amorphous oxides of $\mathrm{Al}_{2} \mathrm{O}_{3}-\mathrm{ZrO}_{2}$ and $\mathrm{SiO}_{2}-\mathrm{ZrO}_{2}$ as suggested by Xie et al. [26] and Zitouni et al. [27].

Table 1 shows the physical properties of $\mathrm{Ni} / \mathrm{Al}_{2} \mathrm{O}_{3}-\mathrm{ZrO}$ and $\mathrm{Ni} / \mathrm{SiO}_{2}-\mathrm{ZrO}_{2}$ catalysts. X-ray fluorescence (XRF) analysis revealed $15.7 \mathrm{wt} \%$ $\mathrm{Ni}$ loading on $\mathrm{Al}_{2} \mathrm{O}_{3}-\mathrm{ZrO}$ support for $\mathrm{Ni} / \mathrm{Al}_{2} \mathrm{O}_{3}$ $\mathrm{ZrO}$ and $16.45 \mathrm{wt} \% \mathrm{Ni}$ loading on $\mathrm{SiO}_{2}-\mathrm{ZrO}_{2}$ support for $\mathrm{Ni} / \mathrm{SiO}_{2}-\mathrm{ZrO}_{2}$. The slight wt\% $\mathrm{Ni}$ increment which differs from the theoretical calculations is attributed to $\mathrm{Al}_{2} \mathrm{O}_{3}-\mathrm{ZrO}_{2}$ and $\mathrm{SiO}_{2}$ $\mathrm{ZrO}_{2}$ support weight loss due to calcination at $500{ }^{\circ} \mathrm{C}$ for $5 \mathrm{~h}$ before Ni impregnation similarly in a report by Fertal et al. [28]. The crystallite size of nickel was determined from the XRD data using Scherrer's equation (Table 1).

In Table 1, the BET surface area and porous structure of $\mathrm{SiO}_{2}-\mathrm{ZrO}_{2}$ support, $\mathrm{Ni} / \mathrm{Al}_{2} \mathrm{O}_{3}-\mathrm{ZrO}{ }_{2}$, and $\mathrm{Ni} / \mathrm{SiO}_{2}-\mathrm{ZrO}_{2}$ catalysts are exhibited. The specific surface area of $\mathrm{SiO}_{2}-\mathrm{ZrO}_{2}$ support significantly decreased from $77.591\left(\mathrm{~m}^{2} / \mathrm{g}\right)$ before $\mathrm{Ni}$ impregnation to $17.985\left(\mathrm{~m}^{2} / \mathrm{g}\right)$, therefore, indicating that $\mathrm{Ni}$ addition has resulted in changes in the physical properties of $\mathrm{SiO}_{2}$ $\mathrm{ZrO}_{2}$. However, the pore volume and pore diameter of $\mathrm{SiO}_{2}-\mathrm{ZrO}_{2}$ remained almost the same before and after $\mathrm{Ni}$ addition. Compared with $\mathrm{Ni} / \mathrm{Al}_{2} \mathrm{O}_{3}-\mathrm{ZrO}_{2}\left(65.938 \mathrm{~m}^{2} / \mathrm{g}\right)$, the $S_{\text {BET }}$ results

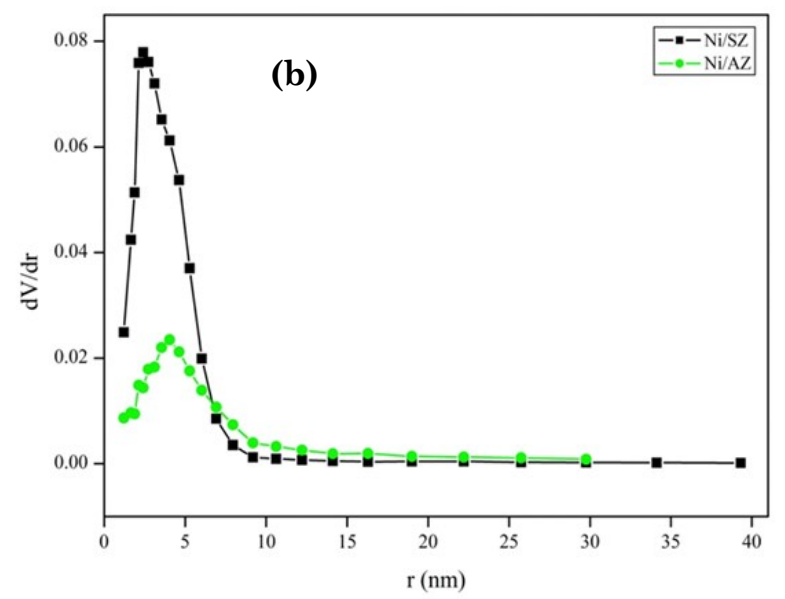

Figure 2. (a) $\mathrm{N}_{2}$ isotherm adsorption-desorption showed the hysteresis loop type IV typical of mesoporous catalyst, (b) pore distribution of $\mathrm{Ni} / \mathrm{SiO}_{2}-\mathrm{ZrO}_{2}$ and $\mathrm{Ni} / \mathrm{Al}_{2} \mathrm{O}_{3}-\mathrm{ZrO}_{2}$ are similar.

Table 1. Physical properties of $\mathrm{Ni} / \mathrm{Al}_{2} \mathrm{O}_{3}-\mathrm{ZrO}_{2}$ and $\mathrm{Ni} / \mathrm{SiO}_{2}-\mathrm{ZrO}_{2}$ showed the increment value of metal loading.

\begin{tabular}{|c|c|c|c|c|c|}
\hline Catalyst & $S_{\mathrm{BET}}\left(\mathrm{m}^{2} / \mathrm{g}\right)^{\mathrm{a}}$ & $\begin{array}{l}\text { Pore volume } \\
\left(\mathrm{cm}^{3} / \mathrm{g}\right)^{\mathrm{b}}\end{array}$ & $\begin{array}{l}\text { Pore diameter } \\
(\mathrm{nm})^{\mathrm{c}}\end{array}$ & $\begin{array}{c}\text { Ni loading } \\
(\%)^{d}\end{array}$ & $\begin{array}{l}\text { Ni crystallite } \\
\text { size }(\mathrm{nm}) \mathrm{e}\end{array}$ \\
\hline $\mathrm{SiO}_{2}-\mathrm{ZrO}_{2}$ & 77.591 & 0.3663 & 6.819 & - & \\
\hline $\mathrm{Ni} / \mathrm{Al}_{2} \mathrm{O}_{3}-\mathrm{ZrO}_{2}$ & 65.938 & 0.1537 & 9.326 & 15.70 & 34.54 \\
\hline $\mathrm{Ni} / \mathrm{SiO}_{2}-\mathrm{ZrO}_{2}$ & 17.985 & 0.3045 & 6.772 & 16.46 & 59.60 \\
\hline
\end{tabular}

a,b,c $\mathrm{N}_{2}$ isotherm adsorption-desorption results, dXRF results, ecalculated from XRD data using Scherrer's equation. 
revealed a smaller specific surface area for $\mathrm{Ni} / \mathrm{SiO}_{2}-\mathrm{ZrO}_{2}$. In addition, $\mathrm{Ni} / \mathrm{SiO}_{2}-\mathrm{ZrO}_{2}$ showed a larger pore volume while the pore diameter remained smaller.

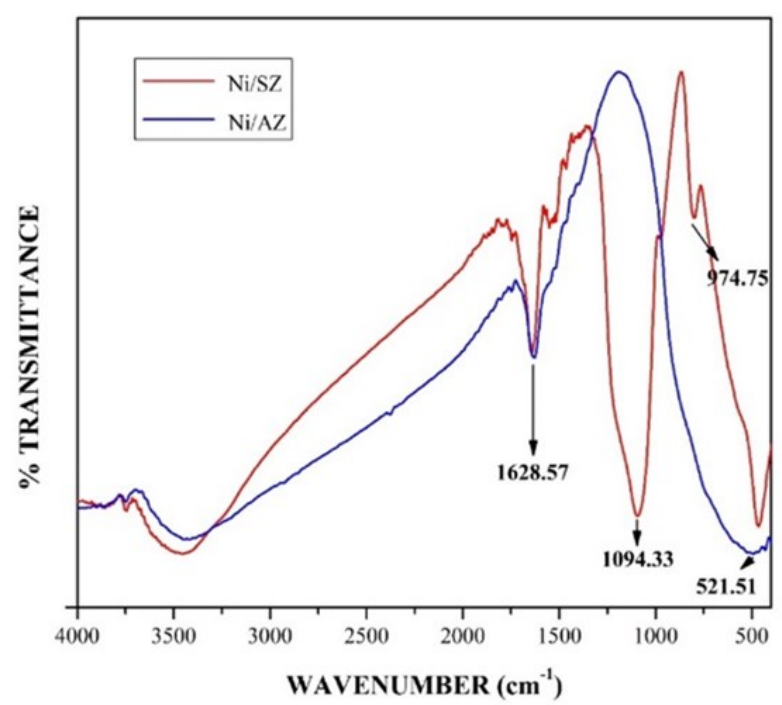

Figure 3. FTIR spectra of $\mathrm{Ni} / \mathrm{Al}_{2} \mathrm{O}_{3}-\mathrm{ZrO}_{2}$ (blue) and $\mathrm{Ni} / \mathrm{SiO}_{2}-\mathrm{ZrO}_{2}$ (red).
Isotherm adsorption-desorption of the catalysts is depicted in Figure 2. $\mathrm{Ni} / \mathrm{Al}_{2} \mathrm{O}_{3}-\mathrm{ZrO}_{2}$ and $\mathrm{Ni} / \mathrm{SiO}_{2}-\mathrm{ZrO}_{2}$ showed a hysteresis loop on $\mathrm{P} / \mathrm{P}_{\mathrm{o}}$ $=0.6-0.8$, typical of type IV mesopore catalyst. The hysteresis type $\mathrm{H} 2$ suggested that there is a blocking on desorption process suggesting the complex pore system with bottle-ink like pore shape with wide neck size [29]. The pore distribution of $\mathrm{Ni} / \mathrm{Al}_{2} \mathrm{O}_{3}-\mathrm{ZrO}_{2}$ is slightly larger compared to $\mathrm{Ni} / \mathrm{SiO}_{2}-\mathrm{ZrO}_{2}$. This is consistent with a previous study by Ulfa et al. [30].

From FT-IR analysis (Figure 3), a strong stretching vibration at $1628 \mathrm{~cm}^{-1}$ indicates the presence of $\mathrm{SiO}_{2}$ in $\mathrm{Ni} / \mathrm{SiO}_{2}-\mathrm{ZrO}_{2}$ and a weak peak at $974 \mathrm{~cm}^{-1}$ confirms the existence of $\mathrm{Si}-\mathrm{O}-\mathrm{Zr}$ bond. A similar observation is made for $\mathrm{Ni} / \mathrm{Al}_{2} \mathrm{O}_{3}-\mathrm{ZrO}_{2}$ with a peak at $1094 \mathrm{~cm}^{-1}$ for $\mathrm{Al}-\mathrm{O}-\mathrm{Al}$ and a peak at $521 \mathrm{~cm}^{-1}$ showing the presence of $\mathrm{Al}-\mathrm{O}-\mathrm{Zr}$ framework in the catalyst as reported by Zhang et al. [31]. The SEM images illustrated in Figure 4 show the morphology of $\mathrm{Ni} / \mathrm{Al}_{2} \mathrm{O}_{3}-\mathrm{ZrO}_{2}$ and $\mathrm{Ni} / \mathrm{SiO}_{2}-\mathrm{ZrO}_{2}$, as a close structure parked with tiny particles of irregular shapes which are attributed to $\mathrm{Ni}$ deposition on the surface of the support [30]. A

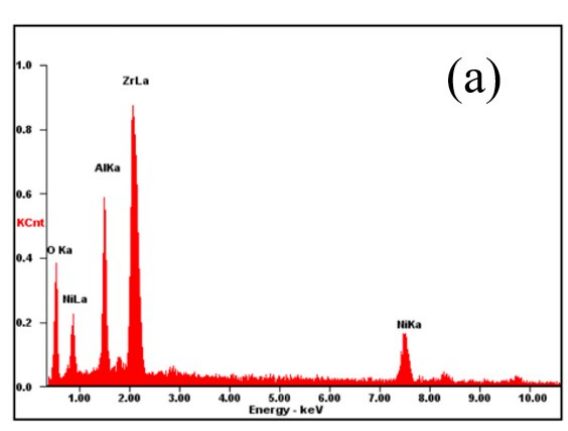

\begin{tabular}{|l|l|l|}
\hline Element & $\boldsymbol{W t} \%$ & At\% \\
\hline OK & 26.32 & 56.98 \\
\hline AlK & 12.70 & 16.31 \\
\hline ZrL & 44.10 & 16.75 \\
\hline NiK & 16.88 & 09.96 \\
\hline Matrix & Correction & ZAF \\
\hline \hline
\end{tabular}


\begin{tabular}{||l|l|l|}
\hline Element & Wt $\%$ & At\% \\
\hline OK & 30.24 & 57.34 \\
\hline SiK & 19.59 & 21.16 \\
\hline ZrL & 24.01 & 07.99 \\
\hline NiK & 26.15 & 13.51 \\
\hline Matrix & Correction & ZAF \\
\hline \hline
\end{tabular}

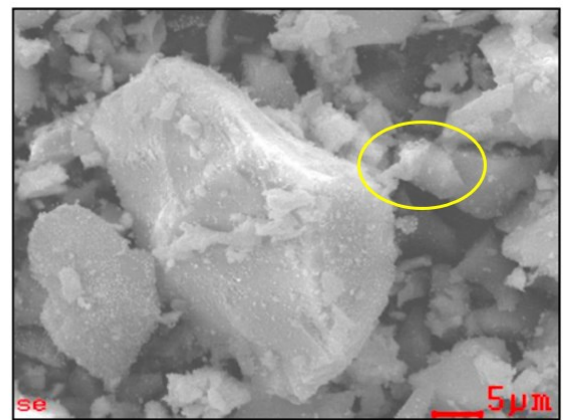

Figure 4. SEM-EDS analysis of (a) $\mathrm{Ni} / \mathrm{Al}_{2} \mathrm{O}_{3}-\mathrm{ZrO}_{2}$ and (b) $\mathrm{Ni} / \mathrm{SiO}_{2}-\mathrm{ZrO}_{2}$ showing surface morphology, elemental content, and distribution.

Table 2. Free fatty acid content from hydrolysis of waste cooking oil.

\begin{tabular}{lcc}
\hline Free Fatty Acid & Carbon Chainc:x & \% Composition $(\text { wt\%) })^{1}$ \\
\hline Tetradecanoic acid & $\mathrm{C}_{14: 0}$ & 1.28 \\
Hexadecanoic acid & $\mathrm{C}_{16: 0}$ & 20.60 \\
9-Octadecenoic acid & $\mathrm{C}_{18: 1}$ & 1.70 \\
11-Octadecenoic acid & $\mathrm{C}_{18: 1}$ & 75.63 \\
Ethyl octadec-9-enoic acid & $\mathrm{C}_{20: 1}$ & 0.79 \\
\hline
\end{tabular}

c:xNumber of carbon and a double bond. ${ }^{1}$ Based on GC-MS analysis 


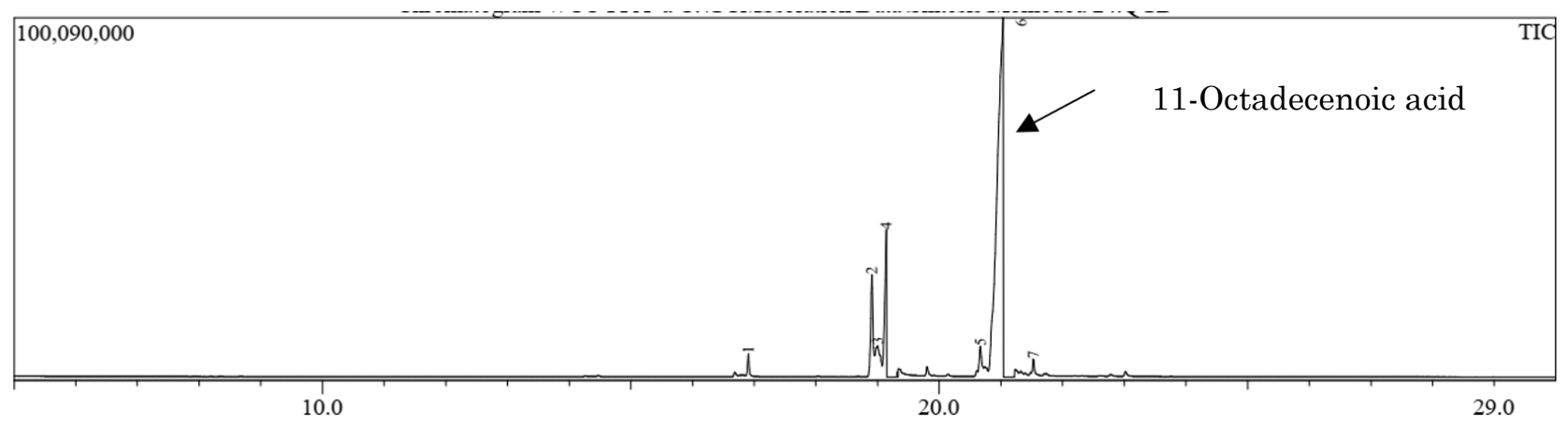

Figure 5. TIC was obtained from GC-MS analysis of waste cooking oil before each reaction. The main component detected is 11-Octadecenoic acid.

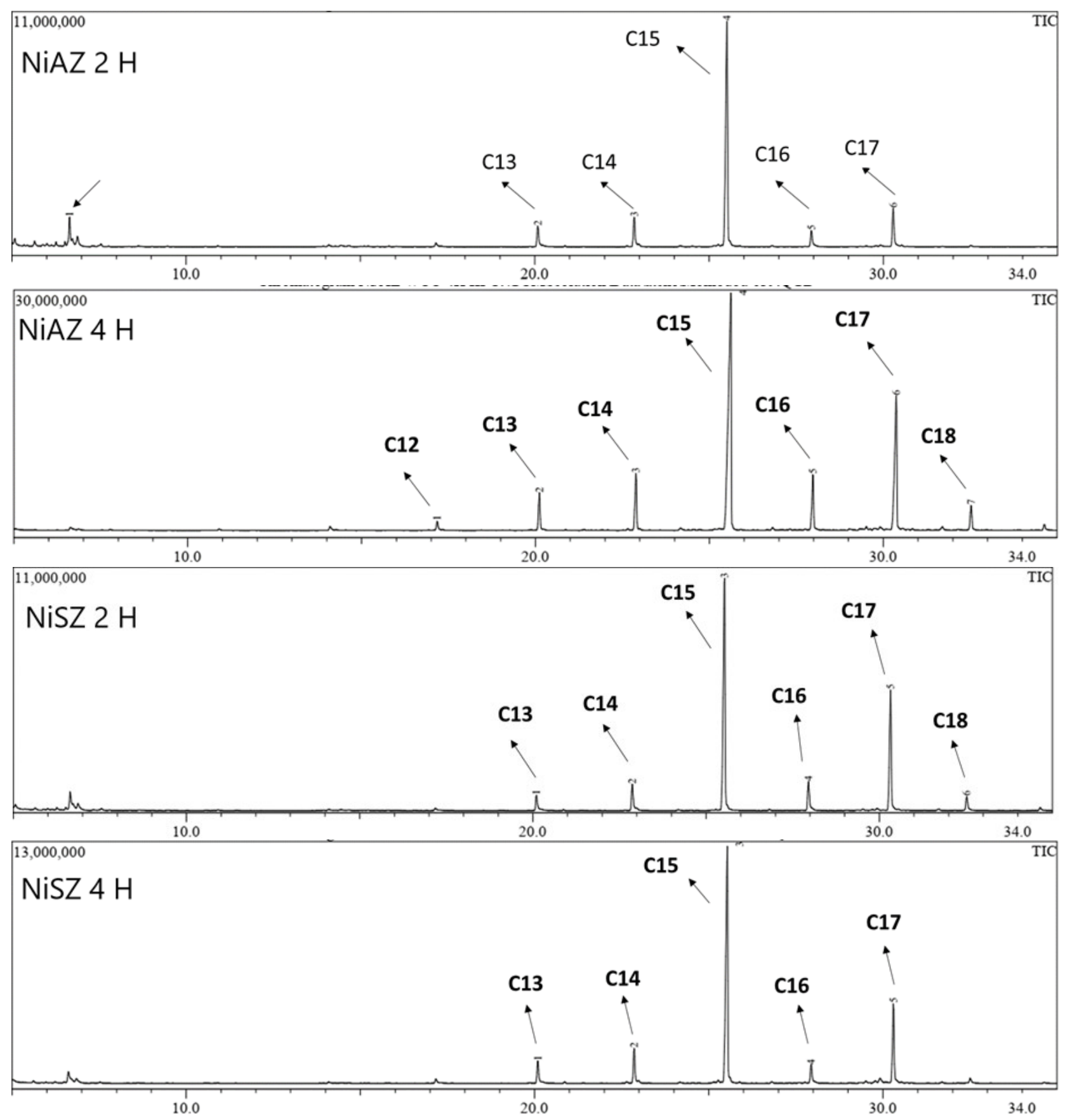

Figure 6. TIC was obtained from GC-MS analysis of products from $\mathrm{Ni} / \mathrm{Al}_{2} \mathrm{O}_{3}-\mathrm{ZrO}_{2}(\mathrm{Ni} / \mathrm{AZ})$ and $\mathrm{Ni} / \mathrm{SiO}_{2}-$ $\mathrm{ZrO}_{2}(\mathrm{Ni} / \mathrm{SZ})$ at respective reaction times. The main product observed is the $n$ - $\mathrm{C}_{15}$ hydrocarbon framework. 
close comparison of the images showed that the surface morphology of $\mathrm{Ni} / \mathrm{Al}_{2} \mathrm{O}_{3}-\mathrm{ZrO}_{2}$ consists of tinier particles than $\mathrm{Ni} / \mathrm{SiO}_{2}-\mathrm{ZrO}_{2}$. The SEMEDS analysis revealed $16.88 \mathrm{wt} \%$ nickel content on the surface of $\mathrm{Ni} / \mathrm{Al}_{2} \mathrm{O}_{3}-\mathrm{ZrO}_{2}$ (Figure 4a) and $26.15 \mathrm{wt} \%$ on $\mathrm{Ni} / \mathrm{SiO}_{2}-\mathrm{ZrO}_{2}$ (Figure $4 \mathrm{~b}$ ). The differences in metal distribution on the surface might be explained by different penetration modes of $\mathrm{Ni}$ on the $\mathrm{SiO}_{2}-\mathrm{ZrO}_{2}$ surface which is neglected even in higher metal loading [32].

\subsection{Hydrodeoxygenation of Waste Cooking Oil}

Before hydrodeoxygenation, WCO was hydrolyzed into free fatty acid using $\mathrm{NaOH}$. The composition of free fatty acid content is tabulated in Table 2. The analysis revealed that 11Octadecenoic acid is the main fatty acid content in our WCO samples (Figure 5). Our analysis agreed with Toba et al. [33], in which the main fatty acid content in a household collected WCO was Octadecenoic acid. Similarly, the Octadecenoic acid was reported as a major fatty acid content in WCO from an unidentified source by Zhang et al. [13].

$\mathrm{Ni} / \mathrm{Al}_{2} \mathrm{O}_{3}-\mathrm{ZrO}_{2}$ (Ni/AZ) and $\mathrm{Ni} / \mathrm{SiO}_{2}-\mathrm{ZrO}_{2}$ (Ni/SZ) catalysts were tested for waste cooking oil (WCO) hydrodeoxygenation to green-diesel. The reaction is carried out independently for each variation of the reaction. The product conversion and distribution were determined by GC-MS analysis (Figure 6) using an internal standard.

All reaction conditions are summarized in Table 3 . In all reactions, the HDO products conversion is $100 \%$ except for the reaction using $\mathrm{Ni} / \mathrm{AZ}$ at $2 \mathrm{~h}$ (entry 1 ). In this reaction by prolonging the time until $4 \mathrm{~h}$ increased the conversion up to $100 \%$ (entry 2). For the reaction using Ni/SZ catalyst, either at $2 \mathrm{~h}$ or $4 \mathrm{~h}$ gave $100 \%$ conversion (entry 3, entry 4 ). It is shown that the HDO reaction using $\mathrm{Ni} / \mathrm{SZ}$ is faster compared to Ni/AZ. Our results are in line with Lycourghiotis et al. [34] and Ding et al. [10], on higher conversion rates of waste cooking oil fatty acid with sulfur-free Ni-based catalysts. HDO activity and selectivity can be significant- ly influenced by catalyst support material. The acidity of support material is an important property to consider. Generally, $\mathrm{Al}_{2} \mathrm{O}_{3}$ exhibits higher acidic strength than $\mathrm{SiO}_{2}$ therefore prone to coke formation [35]. In a report by $\mathrm{Wu}$ et al. [36], the effect of $\mathrm{Al}_{2} \mathrm{O}_{3}$ and $\mathrm{SiO}_{2}$ support on $\mathrm{Ni}_{2} \mathrm{P}$ catalytic $\mathrm{HDO}$ of guaiacol was compared. $\mathrm{Al}_{2} \mathrm{O}_{3}$ showed higher activity for demethylation (DME) and $\mathrm{SiO}_{2}$ promoted deoxygenation (DDO). $\mathrm{SiO}_{2}$ also showed weaker acidic strength with the least coke formation. From our results, it is shown that Ni/SZ facilitated higher deoxygenation leading to better WCO conversion and $\mathrm{Ni} / \mathrm{AZ}$ promoted demethylation by producing more $n$ - $\mathrm{C}_{15}$.

Next, the total green diesel yield is varied from $90.57 \%-97.12 \%$ (Table 3) with a major product yield of $n$ - $\mathrm{C}_{15}$ followed by $n-\mathrm{C}_{17}$. The trend of the product is similar for the use of $\mathrm{Ni} / \mathrm{AZ}$ and Ni/SZ. It is revealed that both catalysts probably promoted hydrogenation followed by decarboxylation and subsequent carbon-chain cracking to give a series of hydrocarbon products consisting of $n$ - $\mathrm{C}_{14}$ to $n$ - $\mathrm{C}_{17}$ as indicated by Zhang et al. [13]. Ni content on AZ and SZ supports (see XRF analysis in Table 1) contributed to higher yields of $n-\mathrm{C}_{15}$ for $\mathrm{Ni} / \mathrm{AZ}$ and $\mathrm{Ni} / \mathrm{SZ}$ as observed because of high $\mathrm{Ni}$ content enhances carbon-chain cracking due to $\mathrm{Ni}$ active species high electron density favorable for $\mathrm{C}-\mathrm{C}$ bond cleavage [35]. However, product $n$ - $\mathrm{C}_{18}$ gives the lowest distribution among all reactions considering that the complex reaction is preferable during the one-step reaction.

In Figure 7, the effect of reaction time on the product distribution is displayed. $\mathrm{Ni} / \mathrm{AZ}$ gave a higher yield of $n$ - $\mathrm{C}_{15}$ at $2 \mathrm{~h}$, compared to $\mathrm{Ni} / \mathrm{SZ}$ under the same reaction time. In this case, the difference in catalyst support and $\mathrm{Ni}$ loading and/or distribution should affect the yield of $n$ - $\mathrm{C}_{15}$. In reports by Hellinger et al. [37] and Popov et al. [38], $\mathrm{Al}_{2} \mathrm{O}_{3}$ is suggested to show a higher specific surface area than $\mathrm{SiO}_{2}$. In our case, the higher BET specific surface area of Ni/AZ is suspected to influence the catalytic activity of $\mathrm{Ni} / \mathrm{AZ}$ due to the adequate space for active $\mathrm{Ni}^{+}$species deposition on the

Table 3. Waste cooking oil $\mathrm{HDO}$ product distribution for $\mathrm{Ni} / \mathrm{Al}_{2} \mathrm{O}_{3}-\mathrm{ZrO}_{2}(\mathrm{Ni} / \mathrm{AZ})$ and $\mathrm{Ni} / \mathrm{SiO}_{2}-\mathrm{ZrO}_{2}$ (Ni/SZ).

\begin{tabular}{|c|c|c|c|c|c|c|c|c|c|c|c|}
\hline \multirow[t]{2}{*}{ Catalyst } & \multirow{2}{*}{ Entry } & \multirow{2}{*}{$\begin{array}{l}\text { Time } \\
\text { (h) }\end{array}$} & \multirow{2}{*}{$\begin{array}{c}\text { Conc. } \\
(\%)\end{array}$} & \multicolumn{5}{|c|}{ Product distribution (\%) } & \multirow{2}{*}{$\begin{array}{l}\text { Total diesel } \\
\text { fraction } \\
(\%) \\
\end{array}$} & \multicolumn{2}{|c|}{$\begin{array}{c}\text { Non-diesel } \\
\text { hydrocarbon }\end{array}$} \\
\hline & & & & $\mathrm{C}_{14}$ & $\mathrm{C}_{15}$ & $\mathrm{C}_{16}$ & $\mathrm{C}_{17}$ & $\mathrm{C}_{18}$ & & $\mathrm{C}_{13}$ & $\mathrm{C}_{12}$ \\
\hline \multirow{2}{*}{$\mathrm{Ni} / \mathrm{AZ}$} & 1 & 2 & 95.14 & 6.96 & 68.97 & 5.05 & 9.59 & --. & 90.57 & 4.57 & $\ldots$ \\
\hline & 2 & 4 & 100 & 7.00 & 58.69 & 5.38 & 20.43 & 4.02 & 95.52 & 3.41 & 1.06 \\
\hline \multirow{2}{*}{$\mathrm{Ni} / \mathrm{SZ}$} & 3 & 2 & 100 & 5.41 & 55.39 & 6.24 & 26.17 & 3.91 & 97.12 & 2.89 & $-\cdots$ \\
\hline & 4 & 4 & 100 & 7.65 & 65.13 & 4.08 & 17.97 & --- & 94.83 & 5.17 & --- \\
\hline
\end{tabular}


surface of the AZ support (Table 1, $S_{\text {BET data). }}$ It is also observed from the SEM image analysis that Ni/AZ catalyst exhibits a smaller particle size compared to Ni/SZ (Figure $4 \mathrm{a}, 4 \mathrm{~b}$ ). On the other hand, the SEM-EDS data suggest that the Ni distribution on the surface of Ni/SZ is higher compared to Ni/AZ even though the



total $\mathrm{Ni}$ loading is almost similar in both catalysts according to the XRF analysis (Table 1, $\mathrm{Ni}$ loading). The high distribution of Ni content observed on the surface of SZ in Ni/SZ (Figure $4 \mathrm{~b})$ could be attributed to the better fatty acid conversion for Ni/SZ as suggested by SánchezCárdenas et al. [39].

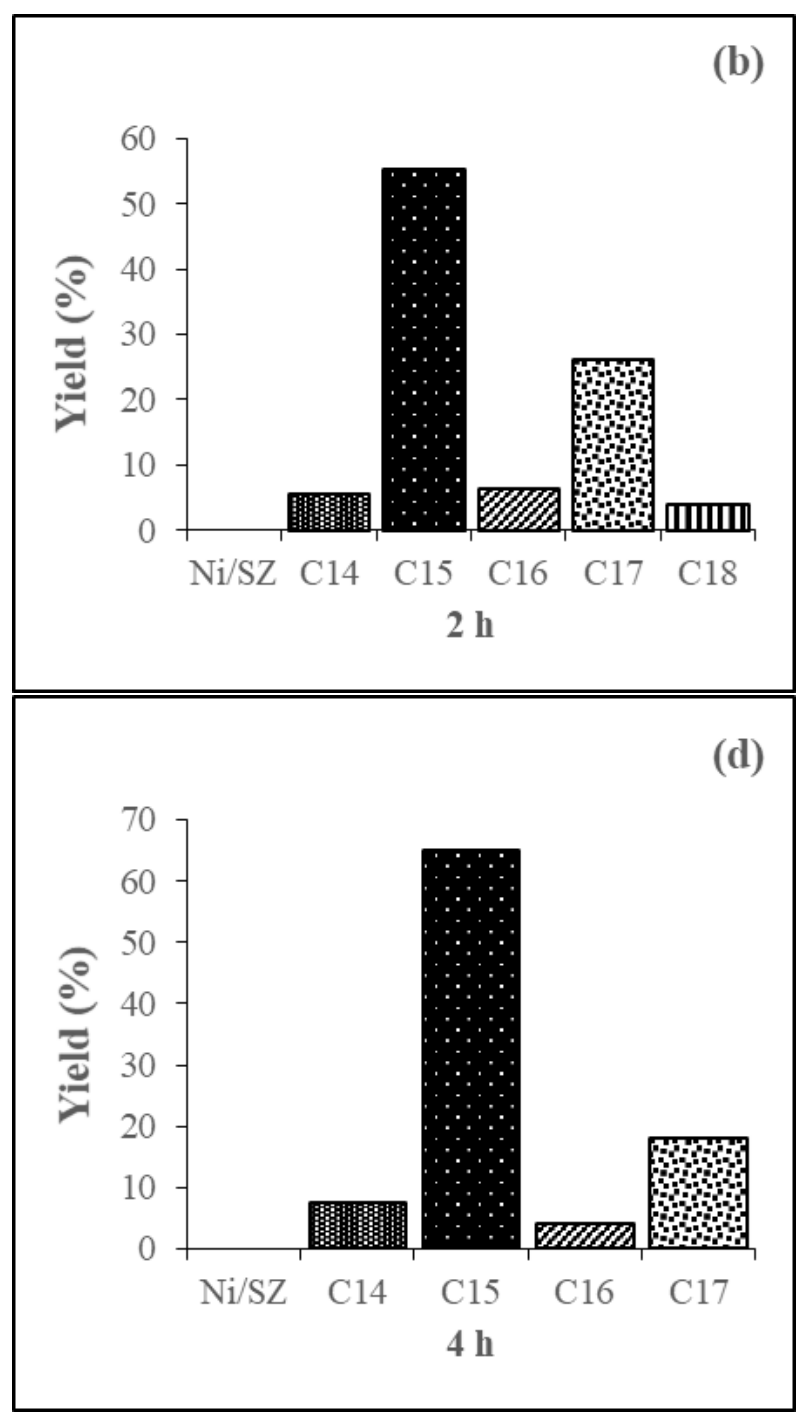

Figure 7. Effects of reaction time on product distribution for $\mathrm{Ni} / \mathrm{Al}_{2} \mathrm{O}_{3}-\mathrm{ZrO}_{2}$ and $\mathrm{Ni} / \mathrm{SiO}_{2}-\mathrm{ZrO}_{2}$.

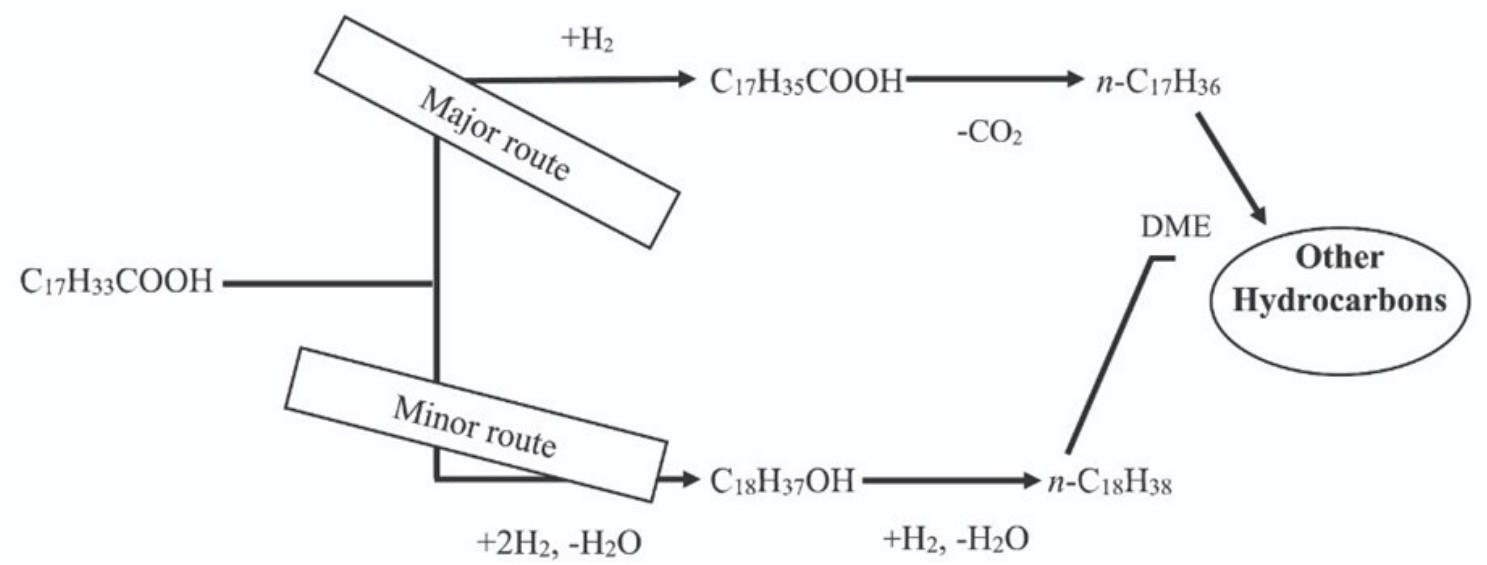

Figure 8. Predicted reaction pathway for WCO hydrodeoxygenation. 
Interestingly, a reserve phenomenon is noticed when the HDO reaction time is prolonged to $4 \mathrm{~h}$. It showed decreasing amount of $n-\mathrm{C}_{15}$ yield for Ni/AZ and an increase of $n-\mathrm{C}_{15}$ by using Ni/SZ. It is predicted that Ni/AZ deactivated in longer reaction time due to a high reaction temperature of $350{ }^{\circ} \mathrm{C}$ which agrees with Monnier et al. [40], on $\mathrm{Al}_{2} \mathrm{O}_{3}$ support deactivation under similar experimental conditions used in this study. In Figure 8, the predicted reaction pathway is highlighted.

\section{Conclusions}

In this study, deposition of $\mathrm{Ni}$ into $\mathrm{Al}_{2} \mathrm{O}_{3}$ $\mathrm{ZrO}_{2}$ and $\mathrm{SiO}_{2}-\mathrm{ZrO}_{2}$ composites by wet impregnation gave mesopore catalysts $\mathrm{Ni} / \mathrm{Al}_{2} \mathrm{O}_{3}-\mathrm{ZrO}_{2}$ and $\mathrm{Ni} / \mathrm{SiO}_{2}-\mathrm{ZrO}_{2}$ based on BET adsorptiondesorption analysis. The obtained $\mathrm{Ni} / \mathrm{Al}_{2} \mathrm{O}_{3}$ $\mathrm{ZrO}_{2}$ and $\mathrm{Ni} / \mathrm{SiO}_{2}-\mathrm{ZrO}_{2}$ were tested for waste cooking oil hydrodeoxygenation to green diesel. Analysis of gas chromatography - mass spectrometry revealed that both catalysts gave green diesel fraction $n-\mathrm{C}_{14}$ to $n-\mathrm{C}_{17}$ with rich content of $n-\mathrm{C}_{15}$ fraction. Notwithstanding, $\mathrm{Ni} / \mathrm{SiO}_{2}-\mathrm{ZrO}_{2}$ showed better activity for waste cooking oil conversion even after prolonging the reaction from $2 \mathrm{~h}$ to $4 \mathrm{~h}$. While $\mathrm{Ni} / \mathrm{Al}_{2} \mathrm{O}_{3}-\mathrm{ZrO}_{2}$ promoted higher selectivity of $n-\mathrm{C}_{15}$ hydrocarbon. Therefore, we conclude that $\mathrm{Ni} / \mathrm{Al}_{2} \mathrm{O}_{3}-\mathrm{ZrO}_{2}$ and $\mathrm{Ni} / \mathrm{SiO}_{2}-\mathrm{ZrO}_{2}$ should be potential catalysts for waste cooking oil conversion to green diesel.

\section{Acknowledgments}

Part of this work was supported financially by the PUPT research grant from KEMENRISTEKDIKTI, Contract no: 054/SP2H/LT/DPRM/IV/2018. We also acknowledged the support of the UB-UTG scholarship program.

\section{References}

[1] Ebadian, M., van Dyk, S., McMillan, J.D., Saddler, J. (2020). Biofuels policies that have encouraged their production and use: An international perspective. Energy Policy, 147, 111906. DOI: 10.1016/j.enpol.2020.111906.

[2] Dolah, R., Karnik, R., Hamdan, H. (2021). A Comprehensive Review on Biofuels from Oil Palm Empty Bunch (EFB): Current Status, Potential, Barriers and Way Forward. Sustainability, $13, \quad 10210$. D O I : 10.3390/su131810210p.

[3] Awogbemi, O., Kallon, D.V.V., Onuh, E.I., Aigbodion, V.S. (2021). An Overview of the Classification, Production, and Utilization of Biofuels for Internal Combustion Engine Applications. Energies, 14(18), 5687. DOI: 10.3390/en14185687.
[4] Ooi, X.Y., Gao, W., Ong, H.C., Lee, H.V., Juan, J.C., Chen, W.H., Lee, K.T. (2019). Overview on catalytic deoxygenation for biofuel synthesis using metal oxide supported catalysts. Renewable and Sustainable Energy Reviews, 112, 834-852. DOI: 10.1016/j.rser.2019.06.031.

[5] Gamal, M.S., Asikin-Mijan, N. Khalit, W.N. A.W., Arumugam, M., Izham, S.M., TaufiqYap, Y.H. (2020). Effective catalytic deoxygenation of palm fatty acid distillate for green diesel production under hydrogen-free atmosphere over bimetallic catalyst CoMo supported on activated carbon. Fuel Processing Technology, $208, \quad 106519$. D O I: 10.1016/j.fuproc.2020.106519.

[6] Khodadadi, M.R., Malpartida, I., Tsang, C.W., Lin, C.S.K., Len, C. (2020). Recent advances on the catalytic conversion of waste cooking oil. Molecular Catalysis, 494, 111128. DOI: $10.1016 /$ j.mcat.2020.111128.

[7] Kamaruzaman, M.F., Taufiq-Yap, Y.H., Derawi, D. (2020). Green diesel production from palm fatty acid distillate over SBA-15supported nickel, cobalt, and nickel/cobalt catalysts. Biomass and Bioenergy, 134, $\begin{array}{lllllllllll}1 & 0 & 5 & 4 & 7 & 6 & . & \text { D } & \text { O } & \text { I }\end{array}$ 10.1016/j.biombioe.2020.105476.

[8] Foo, W.H., Chia, W.Y., Tang, D.Y.Y., Koay, S.S.N., Lim, S.S., Chew, K.W. (2021). The conundrum of waste cooking oil: Transforming hazard into energy. Journal of Hazardous Materials, 417, 126129 . DOI: 10.1016/j.jhazmat.2021.126129.

[9] Perez-Cisneros, E.S., Sales-Cruz, M., LoboOehmichen, R., Viveros-García, T. (2017). A reactive distillation process for cohydrotreating of non-edible vegetable oils and petro-diesel blends to produce green diesel fuel. Computers \& Chemical Engineering, $105, \quad 105-122 . \quad$ D O I : 10.1016/j.compchemeng.2017.01.018.

[10] Ding, S., Li, F., Li, X., Yu, H., Song, C., Xiong, D., Lin, H. (2021). Catalytic hydrodeoxygenation of waste cooking oil and stearic acid over reduced nickel-based catalysts. Catalysis Communications, 149, 106235. DOI: 10.1016/j.catcom.2020.106235.

[11] Li, Z., Huang, Z., Ding, S., Li, F., Wang, Z., Lin, H., Chen, C. (2018). Catalytic conversion of waste cooking oil to fuel oil: Catalyst design and effect of solvent. Energy, 157, 270277. DOI: 10.1016/j.energy.2018.05.156.

[12] Chen, S., Zhou, G., Miao, C. (2019). Green and renewable bio-diesel produce from oil hydrodeoxygenation: Strategies for catalyst development and mechanism. Renewable and Sustainable Energy Reviews, 101, 568-589. DOI: 10.1016/j.rser.2018.11.027. 
[13] Zhang, H., Lin, H., Wang, W., Zheng, Y., Hu, P. (2014). Hydroprocessing of waste cooking oil over a dispersed nanocatalyst: Kinetics study and temperature effect. Applied Catalysis B: Environmental, 150-151, 238-248. DOI: $10.1016 / \mathrm{j}$. apcatb.2013.12.006.

[14] Arun, N., Sharma, R.V., Dalai, A.K. (2015). Green diesel synthesis by hydrodeoxygenation of bio-based feedstocks: Strategies for catalyst design and development. Renewable and Sustainable Energy Reviews, 48, 240-255. DOI: 10.1016/j.rser.2015.03.074.

[15] Oh, S., Lee, J.H., Choi, I.-G., Choi, J.W. (2020). Enhancement of bio-oil hydrodeoxygenation activity over $\mathrm{Ni}$-based bimetallic catalysts supported on SBA-15. Renewable Energ $y, \quad 149, \quad 1-10$. D O I : 10.1016/j.renene.2019.12.027.

[16] Ameen, M., Azizan, M.T., Ramli, A., Yusup, S., Alnarabiji, M.S. (2019). Catalytic hydrodeoxygenation of rubber seed oil over sonochemically synthesized $\mathrm{Ni}-\mathrm{Mo} / \mathrm{Y}-\mathrm{Al} 2 \mathrm{O} 3$ catalyst for green diesel production. Ultrasonics Sonochemistry, 51, 90-102. DOI : 10.1016/j.ultsonch.2018.10.011.

[17] Xing, S., Liu, Y., Liu, X., Li, M., Fu, J., Liu, P., Lv, P., Wang, Z. (2020). Solvent-free hydrodeoxygenation of bio-lipids into renewable alkanes over NiW bimetallic catalyst under mild conditions. Applied Catalysis B: Environmental, 269, 118718 . DO I : 10.1016/j.apcatb.2020.118718.

[18] Shu, R., Lin, B., Wang, C., Zhang, J., Cheng, Z., Chen, Y. (2019). Upgrading phenolic compounds and bio-oil through hydrodeoxygenation using highly dispersed $\mathrm{Pt} / \mathrm{TiO} 2$ catalyst. Fuel, 239, 1083-1090. DOI: 10.1016/j.fuel.2018.11.107.

[19] Ulfa, S.M., Prihartini, D., Taufiq, A. (2019). Structural Characterization of $\mathrm{Ni} / \mathrm{ZrO}_{2} / \mathrm{SiO}_{2}$ Nanocomposites Prepared by Wet Impregnation Route. IOP Conf. Ser.: Mater. Sci. Eng., 515, 012014. DOI: 10.1088/1757899X/515/1/012014.

[20] Sowe, M.S., Masruri, M., Ulfa, S.M. (2019). Synthesis of Ni Catalyst Supported on $\mathrm{SiO}_{2}$ $\mathrm{ZrO}_{2}$ Binary Oxide for Hydrodeoxygenation of Phenol. IOP Conf. Ser.: Mater. Sci. Eng., 546, 072007 . DOI: $10.1088 / 1757$ 899X/546/7/072007.

[21] Lestari, A.R., Suratmo, S., Ulfa, S.M. (2019). Effect of Support on the Hydrodeoxygenation of Phenol using Ni-based Metal Catalysts: $\mathrm{Ni} / \mathrm{SiO}_{2}, \mathrm{Ni} / \mathrm{ZrO}_{2}$, and $\mathrm{Ni} / \mathrm{Al}_{2} \mathrm{O}_{3}$. IOP Conf. Ser.: Mater. Sci. Eng., 546, 072004. DOI: 10.1088/1757-899X/546/7/072004.
[22] Li, F., Ding, S., Wang, Z., Zhixia, Li., Li, L., Gao, C., Zhong, Z., Lin, H., Chen, C., (2018). Production of light olefins from catalytic cracking bio-oil model compounds over La2O3-modified ZSM-5 zeolite. Energy \& Fuels, 32(5), 5910-5922 . DOI: 10.1021/acs.energyfuels.7b04150.

[23] Banerjee, A., Chakraborty, R., (2009). Parametric sensitivity in transesterification of waste cooking oil for biodiesel production-A review. Resources, Conservation and Recycling, $53(9), \quad 490-497$. D O : 10.1016/j.resconrec.2009.04.003.

[24] Ulfa, S.M., Ohorella, R.F., Astutik C.W. (2018). Sequential Condensation and Hydrodeoxygenation Reaction of Furfural-Acetone Adduct over Mix Catalysts $\mathrm{Ni} / \mathrm{SiO}_{2}$ and $\mathrm{Cu} / \mathrm{SiO}_{2}$ in Water," Indones. J. Chem., 18(2), 250. DOI: $10.22146 /$ ijc. 26736.

[25] Ulfa, S.M., Pramesti, I.N., Mustafidah, H. (2018). One-Step Condensation and Hydrogenation of Furfural-Acetone Using Mixed and Single Catalyst Based on Ni/M-Oxide $[\mathrm{M}=\mathrm{Al} ; \mathrm{Mg}]$. IOP Conf. Ser.: Mater. Sci. Eng., 299, 012069. DOI: 10.1088/1757. 899X/299/1/012069.

[26] Xie, Z., Chen, B., Wu, H., Liu, M., Liu, H., Zhang, J., Yang, G., Han, B. (2019). Highly efficient hydrogenation of levulinic acid into 2 -methyl tetrahydrofuran over $\mathrm{Ni}-\mathrm{Cu} / \mathrm{Al}_{2} \mathrm{O}_{3}-$ $\mathrm{ZrO}_{2}$ bifunctional catalysts. Green Chem., 21, 3, 606-613. DOI: 10.1039/C8GC02914H.

[27] Zitouni, A., Bachir, R., Bendedouche, W., Bedrane, S. (2021). Production of bio-jet fuel range hydrocarbons from catalytic $\mathrm{HDO}$ of biobased difurfurilydene acetone over $\mathrm{Ni} / \mathrm{SiO} 2$ $\mathrm{ZrO} 2$ catalysts. Fuel, 297, 120783. DOI: 10.1016/j.fuel.2021.120783.

[28] Fertal, D.R., Monai, M., Proano, L., Bukhovko, M.P., Park, J., Ding, Y., Weckhuysen, B.M., Banerjee, A.C. (2021). Calcination temperature effects on $\mathrm{Pd} /$ alumina catalysts: Particle size, surface species, and activity in methane combustion. Catalysis Today, 382, 120129. DOI: 10.1016/j.cattod.2021.08.005.

[29] Cychosz, K.A., Thommes, M. (2018). Progress in the Physisorption Characterization of Nanoporous Gas Storage Materials. Engineer$i n g, \quad 4, \quad 559-566$. D O I : 10.1016/j.eng.2018.06.001

[30] Ulfa, S.M., Prihartini, D., Mahfud, A., Munandar, R., Pramesti, I.N. (2019). Hydrodeoxygenation of furfural-acetone condensation adduct over alumina-zirconia and silicazirconia supported nickel catalysts. IOP Conf. Ser.: Mater. Sci. Eng., 509, 012132. DOI: 10.1088/1757-899X/509/1/012132. 
[31] Zhang, X., Zhang, Q., Wang, T., Ma, L., Yu, Y., Chen, L., (2013). Hydrodeoxygenation of lignin-derived phenolic compounds to hydrocarbons over $\mathrm{Ni} / \mathrm{SiO} 2-\mathrm{ZrO} 2$ catalysts. Bioresource Technology, 134, 73-80. DOI: 10.1016/j.biortech.2013.02.039.

[32] Gobora, H.M., Hassan, S.A. (2009). A Comparative Study of Surface Characteristics of Nickel Supported on Silica Gel, Y-Alumina, Aluminosilicate. Petroleum Science and Technology, 27(14), 1555-1571. DOI: $10.1080 / 10916460802608677$.

[33] Toba, M., Abe, Y., Kuramochi, H., Osako, M., Mochizuki, T., Yoshimura, Y. (2011). Hydrodeoxygenation of waste vegetable oil over sulfide catalysts. Catalysis Today, 164(1), 533537. DOI: 10.1016/j.cattod.2010.11.049.

[34] Lycourghiotis, S., Kordouli, E., Sygellou, L., Bourikas, K., Kordulis, C. (2019). Nickel catalysts supported on palygorskite for transformation of waste cooking oils into green diesel. Applied Catalysis B: Environmental, 259, 118059. DOI: 10.1016/j.apcatb.2019.118059.

[35] Li, X., Luo, X., Jin, Y., Lib, J., Zhanga, H., Zhanga, A., Xie, J. (2018). Heterogeneous sulfur-free hydrodeoxygenation catalysts for selectively upgrading the renewable bio-oils to second generation biofuels, Renewable and Sustainable Energy Reviews, 82, 3762-3797. DOI: 10.1016/j.rser.2017.10.091.
[36] Wu, S.-K., Lai, P.-C., Lin, Y.-C., Wan, H.-P., Lee, H.-T., Chang, Y.-H. (2013). Atmospheric Hydrodeoxygenation of Guaiacol over Alumina-, Zirconia-, and Silica-Supported Nickel Phosphide Catalysts," ACS Sustainable Chem. Eng., 1(3), 349-358. DOI: 10.1021/sc300157d.

[37] Hellinger, M., Carvalho, H.W.P., Baier, S., Wang, D., Kleist, W., Grunwaldt, J.-D. (2015). Catalytic hydrodeoxygenation of guaiacol over platinum supported on metal oxides and zeolites. Applied Catalysis A: General, 490, 181-192. DOI: 10.1016/j.apcata.2014.10.043.

[38] Popov, A., Kondratieva, E., Mariey, L., Goupil, J.M., El Fallah, J., Gilson, J.-P., Travert, A., Maugé, F. (2013). Bio-oil hydrodeoxygenation: Adsorption of phenolic compounds on sulfided (Co)Mo catalysts. Journal of Catalysis, 297, 176-186. DOI: 10.1016/j.jcat.2012.10.005.

[39] Sánchez-Cárdenas, M., Medina-Valtierra, J., Kamaraj, S.-K., Ramírez, R.-R.-M., SánchezOlmos, L.A. (2016). Effect of Size and Distribution of $\mathrm{Ni}$ Nanoparticles on $\mathrm{Y}-\mathrm{Al}_{2} \mathrm{O}_{3}$ in Oleic Acid Hydrodeoxygenation to Produce nAlkanes. Catalysts, 6, 156. DOI: 10.3390/catal6100156.

[40] Monnier, J., Sulimma, H., Dalai, A., Caravaggio, G. (2010). Hydrodeoxygenation of oleic acid and canola oil over alumina-supported metal nitrides. Applied Catalysis A: General, 382 ( 2 ), $\quad 176-180$. D O I : 10.1016/j.apcata.2010.04.035. 